\title{
Crossing the Lines of Race and Gender: The Quarrel on the Integration of the First Black Dominican Sisters in Natal
}

\section{Philippe Denis}

https://orcid.org/0000-0001-6102-9569

University of KwaZulu-Natal

denis@ukzn.ac.za

\section{Abstract}

Black women expressed the desire to enter religious life in a Dominican Congregation of the Catholic Church of Natal for the first time in 1923. Since all the sisters of the two congregations they wanted to join (initially the Dominican Sisters of Oakford and, later on, the Dominican Sisters of Newcastle) were white, the question was raised of how the black candidates would relate to white sisters. Should they be fully incorporated into the congregation, simply attached to it or kept apart in an independent congregation of black sisters? The decision was in the hands of the women leading these congregations, of the local bishop and of the apostolic delegate sent by Rome to oversee the life of the church. This paper looks at the manner in which race and gender shaped the history of the black sisters in the Dominican Congregations of Oakford, Newcastle and eventually Montebello in inter-war Natal. It argues that, for different reasons and according to different timeframes, the leadership of the Congregations of Oakford and Newcastle ended up consenting to a model of segregation under the control of white sisters. In the Congregation of Newcastle, at least, the black sisters themselves favoured integration.

Keywords: Dominican sisters; Natal; integration; segregation; Oakford; Newcastle; Montebello

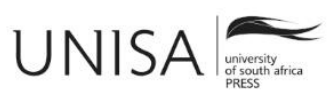




\section{Introduction}

Could white and black religious sisters share the same chapel, dining room and dormitory and have the same superiors in inter-war South Africa? This paper shows that the matter was raised in the early period of the history of the Catholic Church in South Africa. In the case under review-the Dominican Congregation of Newcastle in the Natal province - the white sisters ended up separating themselves from the black novices and professed sisters under their care, asking them to join a diocesan congregation reserved for black sisters.

On 16 January 1939, the 14 black sisters who were completing their training in the Dominican convent of Lennoxton, in the northern Natal city of Newcastle, had the shock of their lives when Bishop Henri Delalle, the head of the Catholic vicariate apostolic of Natal, informed them of what the ecclesiastical authorities had decided for them. ${ }^{1}$ The oldest ones had been staying with white sisters since 1927. Many came from Umsinsini, a mission station on the South Coast in what is today the province of KwaZulu-Natal, South Africa. They were affiliated to the Congregation of the Dominican Sisters of Newcastle, one of the five congregations of Dominican sisters spread over the territories of South Africa and Rhodesia at the time, all active in the field of education, healthcare and evangelisation. In Lennoxton, they shared a building used as a school for black children with a group of white sisters. These 12 or so English, Irish and German sisters, mostly teachers and retirees, appreciated the presence and the occasional assistance of these young black girls who showed such good disposition. Seven black sisters had made temporary profession (or vows), four were novices, two were postulants and one was an aspirant. ${ }^{2}$

The black sisters in temporary vows and the novices wore a religious habit. By decision of Rose Niland, the prioress general and foundress, or Mother Rose as everybody called her, their habit had a different colour - grey and not white as with the white sisters. This signalled that they were not fully integrated into the congregation. And indeed, they slept, ate and prayed separately from the white sisters. This semi-segregation does not seem, on the surface at least, to have created resentment among them. For the black sisters the important thing was to be part the Dominican Congregation of Newcastle, which enjoyed a good reputation in the region. The sisters from Umsinsini and the successive novice mistresses from Lennoxton had inculcated in them the love of St Dominic, the founder of the Order of Preachers in the thirteenth century. They were proud to belong to the Congregation of the Dominican Sisters of Newcastle.

On that day, the bishop told them that, from then on, they would no longer be Dominican sisters of Newcastle. They were assigned to Montebello, a mission station near Dalton three hundred kilometres away where, since 1925, the Dominican Congregation of

1 General Archives of the Dominican Sisters of Catherine of Siena Newcastle Natal, Bushey Heath, Hertfordshire, United Kingdom (hereafter GAN): Annals, 1925-1929, 25.

2 GAN, [Sr Hyacinthe Gilheany], Lennoxton from 1932 onwards, 4-5. 
Oakford had established a novitiate for black sisters. By 1939 Montebello was about to become independent from Oakford under the leadership of Sr Euphemia Ruf, the novice mistress.

The bishop explained to the black sisters that, with the encouragement of the Congregation for the Propagation of the Faith in Rome, he as a bishop, Mother Rose Niland, the prioresses general of Newcastle, and Mother Reginald Buchler, the prioress general of Oakford, had agreed that the two groups of "native" Dominican sisters from the apostolic vicariate of Natal should be in one location and that this location would be Montebello. They were given the choice to accept their transfer or renounce religious life. Should they accept, they had a week to pack their belongings and say goodbye to the other sisters of Lennoxton. On 23 January, guided by Gregory Coffey, a sister whom many of them knew from the time of Umsinsini, they travelled by train to Pietermaritzburg and Glenside near Dalton and from there were taken to Montebello. ${ }^{3}$

\section{Black Sisters in Search of their History}

This story is still remembered today in Newcastle, Oakford and Montebello. It evokes mixed feelings among the sisters who retrospectively empathise for these sisters who were so harshly treated and wonder what agenda the church was pursuing in matters of race relations during this period. The white and black sisters of Newcastle and Oakford respectively are now fully integrated. Those of Montebello, which was canonically established as an independent congregation in 1953 after a transition period of 15 years, are exclusively black but they cooperate with white sisters (and brothers) at different levels.

Several collections of archives document the process that led to the decision to amalgamate the black sisters of Newcastle and Oakford into a new diocesan congregation, to be known as the Congregation of Montebello, which would only admit black sisters while having a white leadership. Traditionally, sisters are good at keeping records. The archives of the Dominican Congregation of the Oakford Sisters in Benoni, north of Johannesburg, and those of the Dominican Congregation of Newcastle Sisters in Bushey Heath, in the United Kingdom, and Boksburg on the East Rand, keep chronicles, minutes of meetings, correspondence and press clippings. In addition, the Archdiocesan Archives of Durban keep documents pertaining to the early history of the Montebello Sisters. ${ }^{4}$

Not much has been written on the history of the black sisters in South Africa. According to Godfrey Sieber, no less than seven diocesan congregations for black sisters were

3 Testimony of a black sister from Lennoxton quoted in Marie-Henry Keane, Neither Daunted nor Deterred the Heritage of Mother Rose Niland (Mariannhill Mission Press, 2016), 167.

4 For a survey of the Catholic archives in South Africa, see Philippe Denis, "The Archives of the Catholic Church of South Africa," Journal of the Eastern and South African Regional Branch of the International Council on Archives 37 (2018): 138-157. 
founded in South Africa, Swaziland and Namibia between the two world wars alone. ${ }^{5}$ The first one, the Daughters of St Francis of Assisi, founded in 1922 by Bishop Adalbero Fleischer, the vicar apostolic of Mariannhill, awaits its historian. ${ }^{6}$ Limited information on the history of the black sisters is provided in the books dedicated by Columba Cleary and her colleagues in 1997, and by Marie-Henry Keane in 2016 on the history of the Dominican Congregation of Newcastle. ${ }^{7}$ The most detailed study of the history of black Dominican sisters is due to the pen of Margaret Schaeffler, who wrote a master's thesis, still unpublished, on the black and coloured sisters in the Congregation of the Dominican Sisters of King William's Town. This Dominican Congregation, from which the Oakford Sisters branched off in the late 19th century, also trained black sisters in a novitiate established in Woodlands, in the Eastern Cape, in $1933 .{ }^{8}$ Mention should also be made of a short section written by Godfrey Sieber on the Congregation of the Benedictine Sisters of Zululand, founded by Bishop Thomas Spreiter, the vicar apostolic of Zululand, in 1929, with the assistance of the Benedictine Sisters of Tutzing. ${ }^{9}$ Marcel Dischl wrote a few suggestive pages on the black sisterhood founded by the Precious Blood Sisters in the early 1930s in the Transkei. ${ }^{10}$ Except for a well-informed chapter in the doctoral thesis of Paula Hinxlage, ${ }^{11}$ an honours dissertation on the succession crisis in the 1970s, ${ }^{12}$ and a journal article also on the apartheid period, ${ }^{13}$ the history of the Montebello Congregation remains largely unwritten.

In this essay we shall examine why, after having established a limited form of racial integration in the 1920s and 1930s, the two congregations concerned-Oakford and Newcastle - ended up, in 1939, separating the black sisters from the white sisters altogether and creating an independent congregation for black sisters under the jurisdiction of the bishop. We shall see that the trajectories of the two congregations

5 Godfrey Sieber, "Religious Life," in The Catholic Church in Contemporary Southern Africa, edited by Joy Brain and Philippe Denis, (Pietermaritzburg: Cluster Publications, 1999), 96.

6 Some information on the early history of the Daughters of St Francis of Assisi is provided in the congregation's website (www.daughtersofstfrancisofassisi.co.za).

7 Columba Cleary, Eleanora Murphy and Flora McGlynn, Being Driven Forward. The Story of Mother Rose Niland and the Foundation of the Newcastle Dominican Sisters (Boksburg: Dominican Sisters, 1997), 97-103; Marie Keane, Neither Daunted nor Deterred, 161-168.

8 Margaret Schaeffler, "The Integration of Black and Coloured Sisters in the Congregation of the King William's Town Dominican Sisters of St Catharina of Siena: The Past, the Present and the Future," unpublished MTh thesis, University of South Africa, 2002, 26-27.

9 Godfrey Sieber, The Benedictines of Inkamana (St Ottilien: Eos Verlag, 1995), 327-329.

10 Marcel Dischl, Transkei for Christ. A History of the Catholic Church in the Transkeian Territories (n.pl., 1982), 169-173.

11 Paula Hinxlage, "Sociopsychological analyses of conflict and its resolutions in a religious organisation," unpublished $\mathrm{PhD}$ thesis, Wright Institute Berkeley, California, November 1990, 224-253.

12 Katrin Kuzmiers, "The Congregation of the Most Holy Rosary of Montebello. Steps towards a Black Leadership, 1972-1987," unpublished honours dissertation, University of Natal, 1997.

13 Catherine Higgs, "Silence, Disobedience, and African Catholic Sisters in Apartheid South Africa," African Studies Review 54 (2011), 1-22. 
were different but interlinked. If Newcastle had stood alone, the black sisters from Lennoxton would have stayed with the white sisters for a long time and may have become fully part of the congregation in the long run.

\section{The Racial Factor}

There are different layers of interaction in the environment in which the first black Dominican sisters of Natal found themselves in the 1920s and 1930s. Their fate was shaped by a combination of factors. The most important ones were race, gender and a third one, which I propose to call — for lack of a better word - the model of church governance.

In inter-war South Africa, race relations were governed in the employment sphere and beyond, by the colour bar policy. Segregation was the default option. Nothing prevented white and black religious women from living under the same roof but the weight of racial prejudice made common life if not impossible, at least complicated. The young African women who felt a "call" to religious life, like Aurelia Mzobe, the first candidate at Umsisini in 1927, in effect placed themselves in the hands of white women whose culture was alien to them. To know their views, we can rely on a certain number of documents-letters of thanks to a superior, declarations of commitment and petitions to the ecclesiastical authorities-written and signed by them. Interpreting these documents, however, is difficult. The question arises of who were the authors: the black sisters or their mentors who told them what to write. In Montebello, Sr Euphemia Ruf made frequent references to the opinion of the black sisters under her care on matters she was disputing with the bishop, the apostolic delegate and the prioress general of the Oakford Congregation. Since the black sisters requested, in these petitions, that more power should be given to $\mathrm{Sr}$ Euphemia, one can legitimately ask whether they genuinely expressed their opinion. It could be a case of ventriloquy.

On the matter of race relations, we can say that the authorities had three alternatives: either the black sisters would be incorporated into the congregation which, until then, was entirely white, or they would be attached to it in a loose and not necessarily permanent way, or they would be separated from it. It is the third option, as we know, that prevailed in 1939. The opinions of the various ecclesiastical leaders, male and female, varied over time, as did those of the white sisters in contact with the black sisters on a daily basis. In the Newcastle Congregation, the context suggests that the white sisters favoured some form of integration, or at least did not oppose it. On the other hand, the leadership, and Mother Rose in particular, insisted that the black sisters should form a "native" sisterhood. In the Oakford Congregation Sr Euphemia, the novice mistress, favoured separation but with the proviso that she and two other white sisters, Sr Josephine Peter and Sr Lucina Angerer, would remain with the black sisters in a position of leadership. She stayed at the helm of the congregation until 1973.

It is important to note that, during this period, the Holy See gave an opinion, though not in a prescriptive way, on the matter of "native" congregations. Following the lead of 
Pope Benedict XV, who had promoted the development of indigenous clergy in the encyclical Maximum Illud of 1919, Pope Pius XI gave guidance, in the encyclical Rerum Ecclesiae of 1926, on the organisation of missions. He had no objection to indigenous people joining older congregations, he wrote, but he felt that it would be "more advantageous" to establish entirely new congregations that "would correspond better with the genius and character of the natives and which would be more in keeping with the needs and the spirit of the different countries." ${ }^{14}$ Implicitly, the pope vindicated the position of those who, like Bishop Fleischer of Mariannhill, created a separate congregation for black sisters rather than aggregating black candidates to an until then exclusively white missionary congregation, where black and white sisters would have been mixed.

\section{Men Directing Women}

A second factor was gender. In the Catholic Church, patriarchy was not only a lived but a canonically instituted reality in the period under review. This is particularly apparent in the manner in which female religious congregations were governed. Since women were not admitted to the priesthood, they depended on men not only for the daily administration of sacraments but for rituals such as the clothing of a novice or the religious profession of a sister. In matters concerning the Newcastle, Oakford and Montebello congregations, the bishop, the apostolic delegate, who represented the Holy See in South Africa, or the prefect of the Congregation for the Propagation of the Faith in Rome, played a crucial role. They had the authority to canonically erect a novitiate and approve the constitutions of the respective congregations.

One would be mistaken, however, to describe the women religious of this period as passive and subservient. Judging from the documents at our disposal, they never questioned male authority in matters of governance. But they knew how to push their agenda in a world of men. Mother Rose, in particular, was one of the first Dominican prioresses general who managed to place her congregation under the patronage of a cardinal protector-Tommaso Boggiani, an Italian Dominican who assumed this century-old function in 1926 - to advance her cause in the Vatican. She could also count on the support of Louis Nolan, a member of the General Curia of the Dominican Order in Rome who served as consultor in the Congregations for Religious and for the Propagation of the Faith.

In the history of the Dominican sisters of Natal, one is struck by the strength of character of two women, Mother Rose Niland, the foundress and prioress general of Newcastle, and Sister (later Mother) Euphemia Ruf, the novice mistress of Montebello, subsequently to become the prioress general of Montebello. There was a considerable amount of agency in these female religious leaders. We are less informed, for lack of reliable sources, on the disposition of the first black Dominican sisters. We know, from reading the Umsinsini mission's chronicles, that some of them went to stay with the

14 Pope Pius XI, Rerum Ecclesiae, 27. 
white sisters against the wish of their fathers and brothers who lamented the loss of ilobololo (bride wealth). ${ }^{15}$ Once admitted, they went out of their way to satisfy the requirements of novitiate and profession. They passed all the necessary exams at school in order to become teachers. It is clear that they were also the agents of their own lives.

\section{Competing Models of Church Governance}

A third line of tension affected the ecclesiastical terrain at the time of the first black Dominican sisters' arrival. It relates to the model of church governance. Before the Second Vatican Council, the Catholic Church in missionary territories was extraordinarily centralised. Rome had to give permission, for example, for the establishment of a store in a mission station. ${ }^{16}$ Any change in the constitution of religious congregations, especially female congregations, had to be approved by Rome.

Yet, the local bishops did not necessarily approve all the Holy See's policies. In the 1920s a subtle but fierce battle was waged in South Africa between the English, Irish and French bishops, who mostly ministered to white settlers and did not see the necessity to ordain black priests in the short term, and the Congregation for the Propagation of the Faith-represented since 1923 by Archbishop Bernard Jordaan Gijlswijk, the apostolic delegate-which wanted a more missionary church. On the question of the indigenous clergy, a new generation of missionary bishops who arrived from the former German colonies after World War One, sided with the apostolic delegate.

This power struggle had repercussions on the question of the black Dominican sisters. As it happens, Gijlswijk was a Dutch Dominican, formerly posted in the Caribbean as a missionary. During the same period - the early 1920s - the prefect of the Congregation for the Propagation of the Faith, Willem van Rossum, and the master of the Dominican Order, Louis Theissling, were also Dutch. The three men, who knew each other, agreed on the need to reform female Dominican life in South Africa and, in June 1921, Gijlswijk was sent to South Africa with the mission to unite the five Southern African Dominican congregations of sisters and encourage the development of a "native" church. ${ }^{17}$ When he returned to South Africa in April 1923, this time with the title of apostolic delegate, he announced to the prioresses general of the five South African Dominican congregations that, by a decision of the Congregation for the Propagation of the Faith, they no longer depended on the local bishop but on him, in his

15 GAN: Old Annals, 1927-1935.

16 Regional Archives of the Dominican Sisters of Catherine of Siena Newcastle Natal, Boksburg, South Africa (hereafter RAN), Folder 6: Congregation for the Propagation of the Faith, Rescript 3525/31 (19 October 1931).

17 Philippe Denis, The Dominican Friars in Southern Africa. A Social History (1577-1990) (Leiden: Brill, 1998), 148-150. 
capacity as representative of the Holy See. ${ }^{18}$ He promptly drew up a constitution for the congregations of South African Dominican sisters, which he tried to implement without any consultation. ${ }^{19}$ Rose Niland, the prioress general of Newcastle, objected on the grounds that her congregation fell under the Roman Congregation for Religious and not that of the Propagation of the Faith. ${ }^{20}$ Aloysia Stoss, the prioress general of Oakford, seems to have been more amenable. The vicar apostolic of Durban, Henri Delalle, expressed his misgivings. ${ }^{21}$

When four black women (later reduced to three) asked to join the Dominican Congregation of Oakford in 1923, Gijlswijk declared that he would "direct" them. In other words, the black sisterhood of Montebello would become his personal project. As we shall see, the novice mistress, Sr Euphemia Ruf, rapidly clashed with Gijlswijk on the manner of envisaging the training of black sisters. In the end, the vicar apostolic gave up the idea of directing the black sisters and Bishop Henri Delalle took over. The merger of the black sisters from Lennoxton and Montebello into one entity resulted from this changing of hands. The tension between the two models of governance-micromanaged by Rome or more reliant on the authority of the bishops - played an important role in the history of the black Dominican sisters in Natal.

\section{"We Do not Want to be Mixed up with the European Sisters"}

About Angela Ngcobo, Flora Gcabashe and Octavia Lushozi, the first black sisters of the Oakford Congregation, we know very little. On entering religious life, they received the names of Sr Siena, Sr Gabriel Possenti and Sr Andreas. Odd as it may seem, it was common in those days to give women religious the names of male saints. By 1947, only $\mathrm{Sr}$ Siena and Sr Andreas were still listed as professed members of the congregation. ${ }^{22}$ $\mathrm{Sr}$ Gabriel Possenti had either died in the meantime or left religious life.

The "Annals," a chronicle compiled by a sister of the name of Mary Joseph, mentions that a novitiate was opened at Oakford, the motherhouse of the congregation, for a group of "girls" who were "anxious to offer themselves to God." Presumably, their homes were in the vicinity of Oakford, 40 kilometres north of Durban. On 11 April 1923, the chronicle reads, the local priest "gave the veil to four girls" and "one was later

18 General Archives of the Dominican Congregation of Oakford, Benoni (hereafter GAO), Montebello 2, file 2, vol. 1: Archbishop Bernard Jordaan Gijlswijk to [Aloysia Stoss], prioress general of Oakford, 2 May 1923.

19 Kathleen Boner, Dominican Women: A Time to Speak (Pietermaritzburg: Cluster Publications, 2000), 212-223.

20 Denis, Dominican Friars, 150.

21 Like all the other vicars apostolic except one, Bishop Henri Delalle refused to attend the welcoming ceremony organised on the occasion of Archbishop Gijlswijk's arrival in South Africa in April 1923 (Denis, Dominican Friars, 152).

22 GAO, Montebello 2, file 2, vol. 1: Petition of the finally professed Sisters of the Natal Congregation of the Most Holy Rosary on various constitutional issues, 47 July 1947. 
dismissed." ${ }^{23}$ The date is significant: the first black Oakford Dominican sisters took the veil four months after the first group of Little Daughter of St Francis of Assisi were clothed in the Mariannhill diocese. ${ }^{24}$ The coincidence of date shows that the pressure exerted by Rome to develop "native" sisterhoods was beginning to take effect in South Africa at the time.

In January 1925, Sr Cecilia Schleich, the newly-elected prioress general of Oakford, decided to transfer the novitiate to Montebello, a mission station founded in 1903 near Dalton in the New Hanover district, which included a school for local black children and a boarding school, soon to be discontinued, for white learners. Sr Euphemia Ruf, the head mistress of the school, was appointed novice mistress. In perpetual vows since 1909, she had been transferred from Oakford to Montebello in 1922 to head the school. As already hinted, she was a strong woman, well organised, opinionated, bullish at times. She was also generous, which explains why, against all odds, the black sisters and the local people in Montebello remained loyal to her for so long. She is the one who steered with utmost determination the process leading to the establishment of an independent congregation for black sisters. She was over 80, in 1973, when she eventually agreed to relinquish power, opening the door to a difficult transition period. ${ }^{25}$

On 11 May 1926 the cardinal prefect of the Congregation for the Propagation of the Faith signed the decree erecting the "Novitiate for Native Postulants to the Sisterhood of the Dominican Congregation of the Third Order"26 and on 15 August 1926, hardly three months later, the three candidates were received as novices in a ceremony led by Joseph L'Hôte, the parish priest of Montebello. ${ }^{27}$

The first manifestation of a conflict between $\mathrm{Sr}$ Euphemia and the apostolic delegate dates from that period. Since the prelate had not been able to come to the reception on account of an illness, Sr Euphemia went to see him in his residence in Bloemfontein to request that when the three black sisters would make profession the following year, they would only bind themselves to the First Part of the congregation's constitutions. ${ }^{28} \mathrm{By}$ this she meant that they would only accept the general principles governing religious life as stipulated in the Catholic Church's code of canon law but not the specific rules of the Oakford Congregation that were spelled out in the second part of the constitutions. As early as 1926, Sr Euphemia already had in mind a different status for the black sisters under her care. As she put it, the black sisters wanted to have in writing whether or not

23 Sr M. Joseph, Annals, 287, quoted in Hinxlage, "Sociopsychological Analyses," 1990, 225.

24 The clothing ceremony took place on 8 December 1922. See www.daughtersofstfrancisofassisi.co.za.

25 Kuzmiers, "The Congregation of the Most Holy Rosary of Montebello"; Higgs, "Silence, Disobedience and African Catholic Sisters in Apartheid South Africa," 9-11.

26 GAO, Montebello 2, file 2, vol. 1: Rescript 1725/26 (11 May 1926).

27 GAO, Montebello 2, file 2, vol. 1: "The true story of Montebello," undated document, 78.

28 GAO, Montebello 2, file 2, vol. 1: Typewritten statement from St Euphemia: Document I. 
they would be "mixed up with the Europeans in future," 29 an option which, according to her, they categorically refused.

Did Oakford plan, at this stage, to integrate the black sisters into the ordinary life of the congregation once their training would be over? We do not know. What we can say for sure is that Rome wanted to leave this possibility open. Propaganda refused any formal distinction between black and white novices. The decree of erection of the Montebello novitiate set three conditions which pointed in the direction of racial equality:

1. In case European postulants should take their novitiate in South Africa, the same novitiate house must be employed for that purpose.

2. The habits of the Sisters European and Native either in the novitiate or after the time of the novitiate must be uniform.

3. The Constitutions must be alike for all the members of the Congregation. ${ }^{30}$

Some time later, the three black sisters sent a letter to the apostolic delegate in which they expressed their fear of being mixed up with the white sisters. "My dear sisters," he replied on 25 January 1927, "who has put this fear in your hearts? Is it the devil who wants to make you lose your vocation?" The thought of mixing them with the white sisters, he explained, had never crossed the mind of their superiors. They were aware of the fact that their "character and customs" were different from those of the white sisters. All they meant was that both groups should have the same duties and privileges. ${ }^{31}$

\section{Open Conflict}

The three sisters made profession on 16 August 1927 in the hands of Bishop Delalle. Their fear of being "mixed up with the European sisters," however, did not subside. The fact that a white postulant who apparently received preferential treatment in the novitiate joined the group in $1931,{ }^{32}$ probably exacerbated the tension.

Things came to a head in January 1932, when Archbishop Gijlswijk sent to the leadership of the Oakford Congregation a document entitled "Regulations for the Native Dominicans in terms of some articles of the II Part of the Constitutions." At first view, this document responded to the concerns of the black sisters of Montebello. It declared that the white and black sisters would be "separated and kept separated in future as well as in the religious life as in the active life." Montebello would be erected as a "district" that would belong to the black sisters living in the district or elsewhere. A "vicaress" would be elected among the white sisters by the black sisters. She would exercise

29 GAO, Montebello 2, file 2, vol. 1: Typewritten statement from St Euphemia: Document I.

30 GAO, Montebello 2, file 2, vol.1: Rescript 1725/26 (11 May 1926).

31 Archdiocesan Archives Durban (hereafter AAD), Montebello Papers: Archbishop Gijlswijk to Sr Gabriel Possenti, Siena and Andreas, 25 January 1927.

32 GAO, Montebello 2, file 2, vol. 1: Archbishop Gijlswijk to Sr Cecilia [Schleich], 19 February 1931. 
authority over the sisters of the district with the proviso that "the extent of that authority [would] be determined by the Prioress General with her Council.".33

Yet, when Sr Mary Claver Maier, the prioress of Oakford, presented the "Regulations" to the black sisters, they refused to endorse them. Gijlswijk was baffled. He started to openly question Sr Euphemia's integrity. While insisting on the need for the black sisters to be "real Dominican sisters" and on the necessity to maintain the constitutions, he wrote to Sr Mary Claver, he had tried to comply with all their wishes. "I am sorry to hear that Sr Euphemia, who is said having so much influence [with] the native sisters, has failed to make them understand that they have no reason to complain anymore."34

A few days later, Sr Cecilia Schleich, the prioress general, summoned Sr Euphemia to the motherhouse and asked her to accept the second part of the constitution. She refused. She then had a tense meeting with the apostolic delegate, who was in Oakford at the time. She related it in the following terms in a later document:

Reverend Mother General went to his Grace and Sister Euphemia was called to the Parlour at Oakford in the presence of His Grace and Mother General. His Grace said: "Sister it is only you who causes all that trouble and who will not give in. If you were to tell the Native Sisters that the Second Part of the Congregations of the Oakford Sisters is alright they would believe you." Sister Euphemia was silent and heartbroken. ${ }^{35}$

Two years later, Sr Cecilia instructed Sr Euphemia to accept the regulation "in virtue of holy obedience" and a revised text was sent to the apostolic delegate in Bloemfontein. She nevertheless continued to ignore it on the grounds that the black sisters had never endorsed them. ${ }^{36}$

For Gijlswijk, that was too much! Around that time, he decided to throw in the towel and withdrew from all responsibility in Montebello. Bishop Delalle stepped in "to regularise the situation of the black sisters," as he explained to Cardinal FumasoniBiondi, the prefect of the Congregation for the Propagation of the Faith in subsequent correspondence. ${ }^{37}$ The decision to create a separate diocesan congregation of black sisters under his care was made during a visit ad limina to Rome in June $1938 .{ }^{38}$

33 AAD, Montebello Papers: Regulations for the Native Dominicans in terms of some articles of the II Part of the Constitutions.

34 AAD, Montebello Papers: Archbishop Gijlswijk to Sr Mary Claver [Meier], 7 February 1932.

35 GAO, Montebello 2, file 2, vol. 1: Typewritten statement from Sr Euphemia: Document VI.

36 GAO, Montebello 2, file 2, vol. 1: Typewritten statement from Sr Euphemia: Document Document IX.

37 AAD, Montebello Papers: Bishop Henri Delalle to [Cardinal Pietro Fumasoni-Biondi], 28 October 1939.

38 GAO, Montebello 2, file 2, vol. 1: Archbishop Gijlswijk to Sr Reginald (Buchler), 14 September 1938. A visit ad limina is a formal visit Catholic bishops are expected to make to the pope and the Roman Curia every five years. 
In this violent confrontation between a German woman speaking on behalf of the black sisters and a Roman prelate, it is the woman who won. It is clear that her agenda was to gain full and unhindered control of Montebello. She had no time for Gijswijk, whom she perceived as ill-informed and despotic. The apostolic delegate and the prioress general of Montebello made important concessions but — quite understandably from an institutional point of view - they did not give Sr Euphemia the latitude to determine, as the "Regulations" said, the extent of her own authority. In the end, however, she forced Oakford to grant her foundation full autonomy.

And the black sisters? All along Sr Euphemia claimed to speak on their behalf. They did indeed take initiatives. The three pioneers sent a letter to the apostolic delegate in 1927 and, when pressed to endorse the "Regulations" he had drafted for them, the black sisters refused to do so. Did they really refuse to be mixed up with the white sisters? Placed in similar circumstances, as we shall see in the next section, the black sisters of Lennoxton never expressed the fear of living with white sisters. More likely is the hypothesis that $\mathrm{Sr}$ Euphemia, who wanted to have exclusive control over the black sisters, manipulated them into believing that mixing up with white sisters was the problem. It is rather strange, in an environment where obedience to religious superiors is highly rated, to see young black women defy without a blink the authority of an archbishop and of a prioress general. There is no doubt, as Gijlswijk exclaimed in a bout of irritation, that Sr Euphemia held sway over the black sisters. The end of the game was not to have a church movement controlled by black people, as was the case of the Ethiopian churches that were flourishing during the same period, but a congregation of black sisters under the authority of a white woman.

\section{Lennoxton}

As we have seen, the transformation, decided during the course of 1938 in Rome, of Montebello into a separate diocesan congregation under the jurisdiction of Bishop Delalle had an immediate effect on the lives of the black sisters from Lennoxton. To put this episode into perspective, let us briefly review the history of the second group of black Dominican sisters.

Black sisters are mentioned in the records of the Newcastle congregation for the first time in 1927. That year, the chronicle of the Umsinsini mission reads, "some Native girls, former pupils at the Mission School of the Sacred Heart expressed the desire to become Sisters." 39 The first one, Aurelia Mzobe, had been a boarder at the school run by the sisters five years previously. She decided to join religious life after a serious illness. The sisters referred her to the house of the Little Daughters of St Francis in nearby Mehlomnyama. However, after a short period with them, she chose instead to stay with the Dominican sisters. ${ }^{40}$ By December 1930, eight black women had been accepted as aspirants and a further 15 had been received into the Sodality of the Children

39 GAN: Annals 1925-1929, Umsinsini.

40 GAN: Old Annals, 1. See Cleary et al., Being Driven Forward, 97-98. 
of Mary. ${ }^{41}$ The aspirants seem to have stayed with the white sisters who lived in a building adjacent to the school, later to be replaced by a spacious convent. The most senior sister, Sr Gregory Coffey, had great plans for them. Her ardent desire, her colleague Sr Paula Heussen wrote in a memoir, "was to begin an African Sisterhood the members of which would be able to continue the work [the Newcastle Sisters] had so successfully begun among their people." 42

This situation continued until January 1932 when Mother Rose Niland, the prioress general, came to Umsinsini to publicly celebrate, as in the other houses of the congregation, her Golden Jubilee. The chronicle relates that, on this occasion, the aspirants "approached her with the request to admit them into the Congregation." Mother Rose reportedly said that she would "give them a trial and take them to Lennoxton." ${ }^{43}$ Considering how hierarchically structured religious life was at the time, it is doubtful that the black women's application for admission was made in such a way. Sr Gregory, who had gone to Rome the year before as a delegate to the general chapter, ${ }^{44}$ and the other sisters surely did some ground work. They must have known that Mother Rose was in a position to give a positive response to the black candidates because, the year before, the Newcastle congregation had decided to transfer the boarding school for white boys operating until then at Lennoxton to another venue in Newcastle and replace it with a school for black children known as St Lewis Bertrand School. ${ }^{45}$ There would be enough room, therefore, for a black novitiate.

On 7 April, Sr Gregory Coffey brought five candidates, including Aurelia Mzobe, to Lennoxton and a further two on 27 May. By 1933 there were 11. The candidates shared their time between classes at St Lewis Bertrand School and manual labour in the convent. At first, they were housed in two large rooms in the sanatorium but when these proved too small, they were transferred to the second and third story of the old school building where they were "completely removed," the chronicle noted, from the community of white sisters. ${ }^{46}$

On 20 November 1933, Mother Rose, then residing in Rome, submitted to the Congregation for Religious a request for the erection of an "indigenous novitiate of the Dominican Sisters of Newcastle," which was granted on 11 December $1933 .{ }^{47}$ The wording suggests that the novitiate of Lennoxton was restricted to black sisters, which

41 GAN: Annals 1930-1934, Umsinsini.

42 RAN: Paula (Heussen), "Mission work at Sacred Heart Mission and Lennoxton, 19311969," 3.

43 GAN: Annals 1935-1938, 11.

44 GAN: Annals 1930-1934, Umsinsini.

45 Cleary et al., Being Driven Forward, 180. St Thomas School, Denis Hurley, the future archbishop of Durban, spent a few years as a boarder at St Thomas' Boys' School in Lennoxton.

46 GAN: Annals 1935-1938, 78.

47 RAN, vol. 3, Official Document: Congregation for the Propaganda of the Faith, Rescript 7703/33 (11 December 1933). 
was not a problem since there was a novitiate for white sisters in England and in Rome. It did not specify the status of the black sisters within the Newcastle congregation: did they fully belong to it or only partially and provisionally? The minutes of the Council and a subsequent document, however, reveal that the leadership of the Newcastle Congregation had chosen the second option.

On 9 December 1933, two days before the decree of erection was signed, the Council of the congregation resolved that the black sisters would wear a habit of a different colour, a trivial but symbolically significant decision, since it concerned the religious identity of the sisters:

Later on the Constitution for the Native Sisters will be drawn up and their dress discussed. As for us we have considered the latter [I]t will be somewhat like the Dominican Habit but of grey material. However, all the details will be discussed in full at a later meeting. ${ }^{48}$

On 16 January 1934 the Council appointed Sr Perpetua Heppler as novice mistress. She would be a novice mistress, the minutes read, "for the new Native congregation which is now fully established." Her brief was to develop this new congregation in the same spirit as the Newcastle Congregation:

She will train them to follow as closely as possible our Rule and Constitutions, studying carefully how they are able to adapt themselves to Religious discipline and to the existing Rule and Constitutions so that when the Congregation develops they may be modified for them to suit their life and work.

The novices, the Council also decided, were to live in "completely separate quarters under the care of the Mistress.. 49

Two months later, in response to a query of Giuseppe Monticone, the archivist of the Congregation for the Propagation of the Faith, Louis Nolan, the Dominican friar who acted as the canonical adviser of the Newcastle Congregation and unquestionably echoed Mother Rose's opinions, made the following statement, which is very revealing:

When it will be necessary (after our death) to erect the Native Congregation of which the seed is now sown in hope-without doubt the superiors interested will have recourse to the competent authority for the necessary permission. ${ }^{50}$

\section{Mother Rose's Dilemma}

How much the sisters on the ground, in Lennoxton for example, knew of the decisions made by their leadership in the motherhouse - a place called Villa Rosa in Rome-is

48 GAN: Minutes of the Council, 9 December 1933.

49 GAN: Minutes of the Council, 16 January 1934.

50 RAN, vol. 3, Official Documents: [Louis Nolan] to [Giuseppe Morticone], 24 March 1934. 
open to conjecture. One should not assume that the prioress of Lennoxton, Sr Mary Lewis Kostial, and the novice mistress, Sr Perpetua Heppler, had a clear understanding of the canonical status of the black sisters under their care. The fact that they lived in separate quarters did not mean that they belonged to a separate congregation. Before Vatican II, it was common in religious houses to strictly separate novices and students from senior community members. As for the black sisters themselves, the early chronicles suggest that they entered religious life with the intention of becoming sisters of Newcastle, not sisters in a separate congregation. ${ }^{51}$

In the 1930s, the goal of an independent congregation for black sisters appeared quite remote. If things had followed their course, the white and black sisters of Newcastle might have ended up being fully integrated by the middle of the 20th century, as happened in the Dominican congregations of King William's Town in South Africa and Salisbury (now Harare) in Rhodesia. ${ }^{52}$ The conflict between Archbishop Gijlswijk and $\mathrm{Sr}$ Euphemia precipitated an evolution that would have taken place later, or might have never happened. When the apostolic delegate chose to withdraw from Montebello, the only authority capable of replacing him - in a church where the superior status of men was undisputed - was the local bishop. And if Montebello fell under the jurisdiction of the vicar apostolic of Durban, it was only a matter of time before it became a diocesan congregation.

Following the same logic, the Congregation for the Propagation of the Faith decreed, on 19 March 1937, that all "native" sisterhoods in the vicariate of Natal should be diocesan under the jurisdiction of the local bishop. ${ }^{53}$ This did not mean that the black sisters from Lennoxton should necessarily fall under the bishop's jurisdiction. If they were incorporated into the congregation, Propaganda pointed out, there was no need to review their status. But they could not remain in an ambiguous position-neither incorporated nor separated - as they were since 1932.

In short, Mother Rose had to decide whether the black sisters would be fully integrated into the congregation, or whether they should be on their own. It is difficult to establish whether the matter had been debated. The minutes of the Council are laconic on this question. It appears that Mother Rose made up her mind after a visit by Bishop Delalle to Rosary Priory in Bushey Heath near London, where the motherhouse of the congregation had been transferred in the meantime, around September 1938. According

51 GAN: Old Annals, 1927-1935.

52 Schaeffler, "The Integration of Black and Coloured Sisters in the Congregation of the King William's Town Dominican Sisters of St Catharina of Siena"; Ferreira Weinzierl, 100 Years of Evangelisation 1891-1991. Dominican Sisters in Zimbabwe (Harare: Dominican Sisters, 1991). The black sisterhood trained by the Precious Blood Sisters in the Transkei were also incorporated into the congregation at a later stage (information kindly provided by $\mathrm{Sr}$ Annette Buschgerd CPS).

53 The date is mentioned in Mother Rose's letter to Pope XI of 22 October 1938 a copy of which is included in the minutes of the Council of the Newcastle congregation held on the same day. See Cleary et al., Being Driven Forward, 99-100. 
to one of the chronicles of the congregation, the bishop and the prioress general made the decision to transfer the black sisters to Montebello "together." 54

The minutes of the Council meeting held on 9 October 1938 leave no doubt on the fact that the Newcastle Congregation could have kept the black sisters if it had been willing to unrestrictedly incorporate them:

Propaganda wants the Native sisterhood in S. Africa to be Diocesan and that would mean that for us Bishop Delalle would in his Vicariate collect all Native Sisters belonging to us or any other Convent in Natal in one Institute which would be entirely under this care. ... If we wish to hold on to these Native Sisters, then Propaganda insists that they become entirely incorporated with our Congregation, conventing with us in every part of our daily life in Refectory, Chapter, Community room etc..$^{55}$

As the discussions held in 1933 and 1934 indicate, the leadership of the Newcastle Congregation never envisaged a full integration of the black sisters into the congregation as the Dominican Sisters of King William's Town ${ }^{56}$ and, on the men's side, the Oblates of Mary Immaculate were busy experimenting, not without challenges, during the same period ${ }^{57}$ In a church deeply impregnated by the colonial mindset, the idea of black and white sisters living a full common life was difficult to imagine. Segregation was the order of the day. Mother Rose and the sisters who surrounded her were people of their time. In matters of race relations and in many other areas the churches, and the congregations of religious sisters in particular, have gone a long way since then.

When Mother Rose heard, in early January 1939, that the rumour of an imminent transfer of the black sisters had started to circulate and that Bishop Delalle was about to arrive in Lennoxton, she did not think twice. She replied: "Send the sisters to Montebello at once." The story is included in a chronicle kept by Hyacinthe Gilheany, a sister residing in Lennoxton at the time. ${ }^{58}$

\section{Conclusion}

The transfer of the black sisters from Lennoxton to Montebello was brutal. This was due, at least for a part, to the lack of communication between the various role-players. A well-planned change would have smoothed the way. More important is the question of who ultimately took the responsibility of separating the black sisters from the

54 GAN, [Sr Hyacinthe Gilheany], Lennoxton from 1932 onwards, 5-6.

55 GAN: Minutes of Council, 9 October 1938.

56 Schaeffler, "The Integration of Black and Coloured Sisters in the Congregation of the King William's," 41.

57 George Mukuka, The Other Side of the Story. The Experience of the Black Clergy in the Catholic Church in South Africa (1898-1976) (Pietermaritzburg: Cluster Publications, 2007), 139-142; Paddy Kearney, Guardian of the Light. Denis Hurley, Renewing the Church, Opposing Apartheid (Pietermaritzburg: University of KwaZulu-Natal Press, 2007), 51.

58 GAN: [Sr Hyacinthe Gilheany], Lennoxton from 1932 onwards, 6. 
Newcastle Congregation. In this matter, Mother Rose was at the same time a victim of circumstances beyond her control and an actor. It was the Congregation for the Propagation of the Faith that decided, in 1937, that there should only be one congregation of black sisters in Natal and that, since Bishop Delalle had taken over from Archbishop Gijlswijk the oversight of the Montebello sisters, Montebello would be that congregation. Mother Rose had no part in this discussion. Propaganda, however, gave her the option of incorporating the black sisters from Lennoxton into the Newcastle Congregation. She came to the conclusion that this was not possible. The result was the transfer to Montebello.

\section{References}

Boner, K. Dominican Women: A Time to Speak. Pietermaritzburg: Cluster Publications, 2000.

Cleary, C., E. Murphy, and F. McGlynn. Being Driven Forward. The Story of Mother Rose Niland and the Foundation of the Newcastle Dominican Sisters. Boksburg: Dominican Sisters, 1997.

Denis, P. The Dominican Friars in Southern Africa. A Social History (1577-1990). Leiden: Brill, 1998. https://doi.org/10.1163/9789004320017.

Denis, P. "The Archives of the Catholic Church of South Africa." Journal of the Eastern and South African Regional Branch of the International Council on Archives 37 (2018): 138157.

Dischl, M. Transkei for Christ. A History of the Catholic Church in the Transkeian Territories, n.pl., 1982.

Higgs, C. "Silence, Disobedience, and African Catholic Sisters in Apartheid South Africa." African Studies Review 54 (2011): 1-22. https://doi.org/10.1353/arw.2011.0032.

Hinxlage, P. "Sociopsychological Analyses of Conflict and its Resolutions in a Religious Organisation." Unpublished PhD thesis, Wright Institute Berkeley, California, November 1990.

Keane, M. H. Neither Daunted nor Deterred: The Heritage of Mother Rose Niland. Mariannhill Mission Press, 2016.

Kearney, P. Guardian of the Light. Denis Hurley, Renewing the Church, Opposing Apartheid. Pietermaritzburg: University of KwaZulu-Natal Press, 2007.

Kuzmiers, K. "The Congregation of the Most Holy Rosary of Montebello. Steps towards a Black Leadership, 1972-1987.” Unpublished honours dissertation, University of Natal, 1997.

Mukuka, G. The Other Side of the Story. The Experience of the Black Clergy in the Catholic Church in South Africa. 1898-1976. Pietermaritzburg: Cluster Publications, 2007. 
Schaeffler, M. "The Integration of Black and Coloured Sisters in the Congregation of the King William's Town Dominican Sisters of St Catharina of Siena: The Past, the Present and the Future.” Unpublished MTh thesis, University of South Africa, 2002.

Sieber, G. The Benedictines of Inkamana. St Ottilien: Eos Verlag, 1995.

Sieber, G. "Religious Life." In The Catholic Church in Contemporary Southern Africa, edited by Joy Brain and Philippe Denis. Pietermaritzburg: Cluster Publications, 1999, 57-96.

Weinzierl, F. 100 Years of Evangelisation 1891-1991. Dominican Sisters in Zimbabwe. Harare: Dominican Sisters, 1991.

\section{Archival sources}

Durban Archdiocesan Archives, Durban (AAD), South Africa.

General Archives of the Dominican Sisters of Catherine of Siena Newcastle Natal (GAN), Bushey Heath, Hertfordshire, United Kingdom.

General Archives of the Dominican Congregation of Oakford, Benoni (GAO), Montebello 2, file 2, vol. 1.

Regional Archives of the Dominican Sisters of Catherine of Siena Newcastle Natal (RAN), Boksburg, South Africa. 